\title{
REFUGIADOS NO BRASIL: RETÓRICA E REALIDADE 1
}

\author{
REFUGEES IN BRAZIL: RHETORIC AND REALITY
}

DOI: $\underline{10.5380 / \text { cg.v10i2.81275 }}$

\author{
Gabriela Santos da Silva² \\ Luiza Pecis Valenti3
}

\begin{abstract}
Resumo
O presente trabalho pretende observar o refúgio no Brasil, a partir da contraposição entre a retórica adotada pelo governo e a realidade dos refugiados no país. Estabelece-se como objetivo analisar criticamente o perfil socioeconômico dos refugiados no Brasil, contrapondo-o com as pré-interpretações negativas atribuídas a este grupo. A partir da abordagem teórica construtivista, os esforços se dividem na análise qualitativa de discursos proferidos pelos governantes brasileiros e no uso de dados presentes no estudo "Perfil Socioeconômico dos Refugiados no Brasil”, promovido pelo Alto Comissariado das Nações Unidas para Refugiados (ACNUR). Conclui-se que os discursos proferidos pelos governantes tendem a forjar negativamente a identidade dos refugiados, promovendo uma imagem que se estabelece no plano hipotético e que é influenciada pelas suas crenças, despidas da real interpretação da realidade que este grupo enfrenta.
\end{abstract}

Palavras-Chave: Refugiados; Brasil; Retórica; Realidade; Construtivismo.

\begin{abstract}
The present paper intends to observe the refuge in Brazil, based on the contrast between the rhetoric adopted by the government and the reality of refugees in the country. The objective is to critically analyze the socioeconomic profile of refugees in Brazil, contrasting it with the negative pre-interpretations attributed to this group. From the constructivist theoretical approach, efforts are divided in the qualitative analysis of speeches given by Brazilian government officials and in the use of data present in the study "Perfil Socioeconômico dos Refugiados no Brasil", promoted by the United Nations High Commissioner for Refugees (UNHCR). It is concluded that the speeches given by the government have a tendency to negatively forge the identity of the refugees, promoting an image that is established on the hypothetical level and that is influenced by their beliefs, and not in the real interpretation of the reality this group faces.
\end{abstract}

Keywords: Refugees; Brazil; Rhetoric; Reality; Constructivism.

\footnotetext{
${ }^{1}$ Este artigo está licenciado sob a Licença Creative Commons Attribution (CC BY 4.0), sendo permitido o compartilhamento com reconhecimento da autoria e publicação inicial nesta revista.

${ }^{2}$ Mestre e doutoranda em Estudos Estratégicos Internacionais PPGEEI/UFRGS. Pesquisadora no Núcleo de Pesquisa sobre as Relações Internacionais do Mundo Árabe (NUPRIMA). E-mail: silva.gaabii@gmail.com. ORCID: http://orcid.org/0000-0001-6709-0205.

3 Mestre em Estudos Estratégicos Internacionais PPGEEI/UFRGS e doutoranda em Economia do Desenvolvimento PPGE/UFRGS. Professora substituta do Departamento de Economia e Relações Internacionais da UFRGS. E-mail: luizapvalenti@gmail.com. ORCID: http://orcid.org/0000-0003-2746-2566.
} 


\section{INTRODUÇÃO}

A guinada conservadora na política mundial foi pano de fundo para a ascensão de novos líderes com ideais nacionalistas, tanto em países desenvolvidos (como Donald Trump, nos EUA) quanto em países periféricos (como Jair Bolsonaro, no Brasil). Esses líderes, entre outras premissas, defendem a manutenção do Estado-nação, ou seja, entendem a identidade nacional como sendo um indicador de lealdade ${ }^{4}$. Como consequência dos seus entendimentos de identidade nacional e levando em consideração suas propostas de medidas securitárias e nacionalistas, os refugiados são analisados de forma diferente dos cidadãos do Estado e são vistos como um problema de segurança nacional. Entretanto, ao analisar o perfil socioeconômico desses refugiados, é possível perceber uma realidade distinta daquela criada e disseminada pelos líderes nacionalistas.

Por conta da lacuna existente entre a informação que se propaga por policymakers e a realidade vivenciada pelos refugiados, o presente artigo tem como objetivo contrapor ambas as perspectivas. Para tal, analisa o posicionamento que acompanha tal onda política conservadora em paralelo à análise do perfil socioeconômico dos refugiados no Brasil. Dessa forma, metodologicamente a pesquisa se vale da análise qualitativa de documentos, utilizando discursos dos tomadores de decisão no Brasil - e aqueles que o cercam - e o relatório "Perfil Socioeconômico dos Refugiados no Brasil”, o qual mostra, quantitativamente, a realidade dos refugiados no Brasil. A partir dos dados inéditos obtidos no relatório, torna-se iminente interpretar seus resultados qualitativamente, como uma forma de repensar o estudo dessa população altamente vulnerável dentro do território brasileiro.

A fim de compreender a realidade vivenciada pelos refugiados no Brasil, atualmente, é necessário contrapô-la aos discursos disseminados pelo governo comandado desde 2019 por Jair Bolsonaro. Nesse sentido, o artigo se estrutura em três seções principais, às quais se agregam esta introdução e as considerações finais. Em um primeiro momento, o artigo propõe um panorama analítico sobre o tema de migrações e refúgio, apresentando as principais discussões que versam sobre a temática. Na segunda seção, apresenta-se a abordagem teórico-metodológica que será utilizada como base para investigação, detalhando a forma com a qual a comparação entre discurso e realidade será buscada e esclarecendo conceitos centrais para o artigo. Por fim, estes discursos e as medidas adotadas pelo atual governo brasileiro em relação aos refugiados que vivem no Brasil são contrapostos com a análise qualitativa dos resultados evidenciados na pesquisa elaborada pelo Alto Comissariado das Nações Unidas para os Refugiados (ACNUR).

\footnotetext{
4 Para uma discussão aprofundada do conceito de nacionalismo e suas diferentes interpretações, ver Batista Jr. (2019).

5 Elaborado em 2019 por meio de um acordo estabelecido entre o ACNUR no Brasil e as Cátedras Sérgio Vieira de Mello, e teve no quadro de pesquisadores a participação das autoras deste artigo.
} 


\section{A POSIÇÃO DOS REFUGIADOS: DO SISTEMA INTERNACIONAL AO ESTADO-NAÇÃO}

A literatura sobre migrações e refúgio tem caráter interdisciplinar e vem ganhando espaço nos mais diversos campos de estudo. No entanto, os movimentos migratórios não são um fenômeno recente, considerando que, ao longo da história, diversos foram os grupos étnicos que migraram de forma voluntária ou forçada. Diante da expansão desses fluxos, os migrantes passam a ser classificados em diversos grupos, em que pode se citar, por exemplo, os migrantes econômicos - que migram de forma voluntária; os refugiados; os migrantes ambientais, entre outros.

Para Emma Haddad (2008), os refugiados podem ser entendidos como seres que flutuam entre categorias e, com isso, recorrentemente acabam tendo sua identidade forjada pela falta de um sentimento de pertencimento e pelo seu status de outsider. Em outras palavras, por serem entendidos como sendo o "outro", são socialmente construídos como sendo uma ameaça potencial aos Estados. Na mesma linha, Moreira (2014) afirma que os refugiados ocupam posição marginal no Sistema Internacional, tanto em termos identitários, culturais e sociais - por não figurarem como cidadãos do Estado receptor -, quanto em termos jurídicos, uma vez que deixam de exercitar o status de cidadão, também, em seu país de origem. Essa característica de não pertencimento - nem ao país de origem, nem ao país de destino - abre espaço para que os refugiados sejam tratados como um problema que deve ser gerido por meio da participação e ação dos mais diversos atores do Sistema Internacional (MOREIRA, 2014). Esta posição de não pertencimento acaba sendo entendida como algo inerente aos refugiados, fazendo com que seja socialmente construída a ideia de que eles são uma ameaça à soberania dos Estados, pois, ao "desafiarem" a premissa do Estado-nação, colocam em risco a identidade nacional dos Estados.

Para Haddad (2008), o discurso de que refugiados são um problema a ser administrado de forma compartilhada ganha ainda mais protagonismo quando se diferenciam os migrantes econômicos (voluntários) dos refugiados (forçados). Para a autora, o migrante que se desloca de forma voluntária pode ser percebido como uma ameaça potencial aos recursos e ao bem-estar do Estado-nação. Em contrapartida, os imigrantes que são forçados a migrar, ou seja, os refugiados, podem acarretar riscos à estabilidade do Estado soberano devido às questões políticas e de segurança que abrangem - o que pode ser entendido como uma ameaça ainda maior ao Estado que os recebe (HADDAD, 2008). Diante do exposto, pode-se perceber que o refugiado é entendido como um problema desde o momento em que chega ao Estado receptor, por conta da falta de representação e de proteção eficazes que eles recebem.

O discurso de que refugiados são um "perigo" é acompanhado por uma série de alegorias presentes tanto na mídia como nos discursos políticos extremados (HADDAD, 2002; CASTLES, 2003). Um destes mitos é a ideia de uma "crise migratória", a qual tem como consequência o aumento na criminalidade, o terrorismo fundamentalista, o colapso dos sistemas de assistência social, o desemprego em massa, a perda de controle sobre as fronteiras soberanas, o 
enfraquecimento da identidade nacional e a disseminação de doenças. Como resposta ao enfrentamento dessa suposta "crise migratória", tanto a mídia quanto governos enfatizam a necessidade de um controle mais rigoroso nas fronteiras nacionais, da detenção de requerentes de asilo e da deportação de migrantes "ilegais" (CASTLES, 2003).

O reconhecimento de uma imagem dos refugiados como seres perigosos que ameaçam a soberania dos Estados traz como consequência uma série de restrições de direitos no país receptor. O não reconhecimento de qualificações adquiridas em seu país de origem - por meio da não validação de diplomas e certificados profissionais - e a restrição do acesso ao setor formal do mercado de trabalho, o que os encoraja a seguir carreiras pré-existentes no setor informal como uma maneira de garantirem seu sustento no novo país, são alguns exemplos (BETTS et al., 2017). Dessa maneira, mantém-se a recorrente exploração de mão de obra estrangeira que, carente de qualquer outro meio para a manutenção de sua subsistência, abre mão de direitos trabalhistas desde a contratação, e se permite expor a jornadas exaustivas, sendo remunerada a preços mais baixos do que aqueles praticados no mercado (LAURETTI, 2017).

Betts et al (2017) defendem que existem diversas maneiras de se abordar a temática do refúgio. No entanto, as abordagens atuais tendem a ignorar as habilidades, os talentos e as aspirações dos refugiados. Afirmam ainda que, como pessoas, os refugiados não são diferentes dos demais cidadãos; eles são pessoas comuns em circunstâncias excepcionais, que possuem distintas habilidades e qualificações, além de um desejo de trabalhar e contribuir para o país receptor, e, por isso, não devem ser considerados um fardo para aqueles (BETTS et al, 2017). Diante do exposto, ao invés de se assumir que os refugiados são seres dependentes de assistência constante, cabe aos Estados incentivá-los a se estabelecerem no país, uma vez que possuem potencial de contribuir econômica e socioculturalmente.

Jacobsen (2002) acrescenta que os Estados receptores tendem a criticar uma suposta competição entre refugiados e habitantes locais por recursos escassos - como terra, emprego e recursos naturais -, sobrecarregando a infraestrutura existente. No entanto, os refugiados são detentores de capital humano na forma de mão de obra, habilidades e empreendedorismo, além de serem também canais de fluxos de remessas. Nesse sentido, a presença de refugiados tende a aumentar o bem-estar geral da comunidade do Estado receptor (JACOBSEN, 2002). Jacobsen (2002) e Castles (2003) ainda sugerem que a segurança nacional dos Estados que aceitam migrantes pode ser muito afetada pela maneira como tal Estado incentiva os recém-chegados a se envolverem e se integrarem na vida econômica e política local (CASTLES, 2003; JACOBSEN, 2002). Sendo assim, ao propiciar e incentivar a entrada de migrantes e refugiados por meio de políticas de acolhimento, os Estados podem constatar que esses indivíduos apresentam, na verdade, um ativo em potencial, e não um problema, como fora previamente presumido.

Por fim, Moreira (2014, p. 95-96) afirma que "tratar os refugiados como um 'problema' a ser administrado e resolvido a partir da lógica soberana estatal no sistema internacional, reforça uma 
perspectiva que se furta a reconhecê-los como sujeitos capazes de influir sobre os rumos de suas vidas no país receptor". Nesse sentido, a integração deve ser entendida como multidimensional, em que refugiados tenham acesso ao mercado de trabalho, à educação, à saúde, à política, à cultura, e a outras formas cotidianas de interação social.

\section{O “MUNDO MENTAL” NA CONSTRUÇÃO DA IDENTIDADE DO REFUGIADO}

A partir do que se percebe na literatura, é possível notar as diferentes formas adotadas para observar o refúgio. Ao aproximar esta literatura da realidade de um país latino-americano em desenvolvimento, pretende-se comparar o que se percebe no plano conjectural - a partir de discursos oficiais da presidência e da mídia brasileira - com a realidade vivenciada pelos refugiados. Para começar este esforço, o artigo se baseia, metodologicamente, na Análise Qualitativa de Documentos, a qual se dará, de um lado, por meio de análise dos discursos proferidos pelos governantes brasileiros - como uma forma de compreender o que se estabelece no plano hipotético e na interpretação que se tem da realidade - e, por outro lado, por meio do uso de dados presentes no estudo "Perfil Socioeconômico dos Refugiados no Brasil”, promovido pelo ACNUR (2019), possibilitando assim uma aproximação da realidade vivenciada, de fato, por esses indivíduos.

O uso da Análise Qualitativa de Documentos como método de pesquisa se faz útil neste artigo, na medida em que permite o estudo crítico da política social, por meio da investigação minuciosa das construções sociais envolvidas na prática da fala, as quais podem evidenciar uma linguagem da exclusão social - como no caso dos refugiados. Nesse sentido, foca-se a atenção nestes indivíduos que frequentemente são associados à condição de vulnerabilidade e de marginalização.

Ademais, a Análise Qualitativa de Documentos permite contrapor o “mundo mental” dos discursos com a realidade vivida pelos refugiados. Isso se dá porque é através dessa metodologia que é possível fazer uso da pesquisa bibliográfica e da análise de discursos e conteúdo de forma qualitativa, podendo, por meio da definição de uma literatura especializada, triangular as informações e contribuir para o alcance do objetivo central do artigo: o de contrapor o que se percebe no discurso e na retórica de governantes brasileiros com a realidade vivenciada por refugiados no Brasil. Nesse sentido, de um lado, entende-se como documento para análise da retórica de governantes aqueles presentes na mídia, uma vez que essa é a ferramenta que noticia e publiciza falas, discursos e mensagens governamentais (compreendendo o que se estabelece no plano hipotético e na interpretação que se tem da realidade sobre refúgio) ${ }^{6}$.

\footnotetext{
6 Para o escopo de análise de discursos, priorizaram-se aqueles proferidos por membros do governo nacional (presidência e ministros) ou por pessoas que tem conexões ou fazem parte do círculo pessoal deste (como familiares do presidente, por exemplo). A presidência da república, por ocupar lugar central no país, teve discursos avaliados em espaço temporal anterior à tomada do posto, porque se trata de uma figura que indicava posicionamentos categóricos, importantes de serem avaliados, uma vez que influenciam o posto que ocupa
} 
Por outro lado, a metodologia também integra os resultados do relatório de pesquisa promovido pelo ACNUR, onde 487 refugiados no Brasil foram entrevistados - com uma metodologia quantitativa - em oito Unidades da Federação7 . A análise qualitativa dessas entrevistas permitirá alcançar o que aqui identificamos como a representação da realidade dos indivíduos - a partir do que eles mesmos reconhecem - a qual, em muitos aspectos, difere daquela trazida no "mundo mental", ou seja, nos discursos.

Teoricamente, o artigo se pauta no uso do construtivismo como base para a compreensão do fenômeno migratório e, mais especificamente, da construção da identidade dos refugiados e do reconhecimento delas pelos governantes que os recebem - neste caso, os do Brasil. A construção de identidade e seu reconhecimento são conceitos relevantes para que se possa, então, contrapor discurso e prática; suposição e realidade. Nesse sentido, uma vez que se trabalha com essa contraposição e a comparação do mundo mental (que surge da percepção e do reconhecimento) e do mundo material (referente à realidade dos refugiados), entende-se a importância da abordagem construtivista, a qual argumenta que a realidade é socialmente construída por estruturas cognitivas que dão sentido ao mundo material (ADLER, 1997).

Nesse sentido, é importante esclarecer este termo que é central para a pesquisa - o de refugiado -, principalmente no que diz respeito à legislação brasileira, uma vez que o Brasil é o país receptor. Neste país, em 1997, incorporou-se na Lei 9474/97 características presentes na Convenção de Genebra de 1951 e na Declaração de Cartagena de 1984 para definir pessoas elegíveis para a classificação de refugiados. Dessa forma, um refugiado seria uma pessoa que

(...) temendo ser perseguida por motivos de raça, religião, nacionalidade, grupo social ou opiniões políticas, se encontra fora do país de sua nacionalidade e que não pode ou, em virtude desse temor, não quer valer-se da proteção desse país, ou que, se não tem nacionalidade e se encontra fora do país no qual tinha sua residência habitual em consequência de tais acontecimentos, não pode ou, devido ao referido temor, não quer voltar a ele (ACNUR, 1951, s/p).

Ademais, refugiados também podem ser

(...) pessoas que tenham fugido dos seus países porque a sua vida, segurança ou liberdade tenham sido ameaçadas pela violência generalizada, a agressão estrangeira, os conflitos internos, a violação maciça dos direitos humanos ou outras

\footnotetext{
hoje. A filtragem para a análise dos discursos se deu por meio da centralidade do conceito de refúgio nas buscas entre os jornais e revistas. Destaque também foi dado àquelas notícias amplamente divulgados nos diversos veículos de informação, por conta das afirmações contundentes feitas pelos policy-makers.

7 "Para a realização do trabalho de campo foi elaborado desenho amostral que levou em consideração a amostragem intencional por cotas, para estimar proporções das variáveis sociodemográficas, sendo estabelecido um total de 500 entrevistas. Essa amostra foi aplicada em 14 cidades, distribuídas em oito Unidades da Federação - São Paulo, Rio de Janeiro, Paraná, Rio Grande do Sul, Distrito Federal, Santa Catarina, Minas Gerais e Amazonas - que concentram 94\% dos refugiados sob a proteção do governo brasileiro. A alocação do número de entrevistas em cada um dos estados levou em consideração sua participação relativa no total da amostra. Da amostra inicial de 500 refugiados, foram entrevistados 487 indivíduos ou 97,4\% do total previsto" (ACNUR, 2019, p. 5).
} 
circunstâncias que tenham perturbado gravemente a ordem pública (ACNUR, 1984, $\mathrm{s} / \mathrm{p})$.

Assim, percebe-se que, uma vez que esses indivíduos chegam ao país de destino, já são categorizados e identificados - e isso pode ter resultados positivos ou negativos. Isso porque a maneira com a qual essa identificação pode ser manipulada diverge a partir dos discursos daqueles que tem de lidar com a questão: os governantes. Fairclough (2003) apresenta os discursos como formas de representar o "mundo material" e o "mundo social" pelo "mundo mental". Nesse processo, os discursos são carregados de perspectivas diversas, uma vez que o "mundo mental" é composto pelos pensamentos, sentimentos e crenças de quem profere o discurso.

Os discursos não apenas representam o mundo como ele é (ou melhor, como é visto), mas também são projeções, imaginários, representando mundos possíveis diferentes do mundo real (...). As relações entre discursos diferentes são um elemento das relações entre pessoas diferentes - elas podem se complementar, competir umas com as outras, uma pode dominar outras e assim por diante (FAIRCLOUGH, 2003, p. 124, tradução livre).

Percebe-se, por meio dos discursos, que a realidade pode ser percebida como socialmente construída. Nesse sentido, trabalhar com os conceitos de identidade e reconhecimento se faz importante, porque permite captar como o mundo mental (carregado de crenças, projeções e imaginários) pode afetar a forma através da qual se reconhece o mundo material - um reconhecimento que pode, em muitos aspectos, escapar do que, de fato, é a realidade vivenciada. Ademais, abre-se a possibilidade para a comparação e contraposição de representações, uma vez que se entende que a realidade, por ser socialmente construída, não é, de fato, imutável ou precisa. Nesse sentido, a abordagem construtivista permite que representações ou reconhecimentos sejam contrapostos de modo a assimilar as nuances do mundo material.

Assim, o que Fairclough (2003) descreve é o processo através do qual o reconhecimento se fará presente nesta dinâmica, fazendo com que os atores passem a existir dentro de determinado cenário, assumindo uma identidade coletiva (GREENHILL, 2008). Este processo de reconhecimento, no entanto, pode resultar em conotações e criações de identidades negativas daqueles que são objeto de análise. Isso porque "identidades (...) são representações prescritivas dos próprios atores políticos e de seus relacionamentos entre si” (KOWERT; LEGRO, 1996, p. 323, tradução livre). Da mesma forma que os próprios atores políticos criam e reconhecem sua identidade, elas podem ser forjadas por outros atores - como através de discursos que denotam negativamente a imagem do refugiado. Identidade e reconhecimento são conceitos intrinsecamente conectados e integram as percepções e categorizações que acompanham a forma com a qual os refugiados são reconhecidos no país de destino - percepções, inclusive, de representantes deste país que deve estar comprometido em integrá-los e protegê-los. 
Por outro lado, a identidade e o reconhecimento também podem fazer parte de uma autopercepção. Assim, para a compreensão da realidade dos refugiados, consideram-se as respostas obtidas em entrevistas - captadas no relatório promovido pelo ACNUR - como uma forma de se contrapor aos discursos proferidos. Desmistificar a conotação negativa que o termo refugiado carrega em diversas práticas discursivas, portanto, faz-se necessário, uma vez que propicia visualizar que são, muitas vezes, as próprias estruturas - e aqueles que delas fazem parte - que, por meio de um reconhecimento forjado, criam identidades negativas para estes grupos, tornando-os invisíveis.

\section{QUANDO A REALIDADE DESAFIA O DISCURSO}

Levando em consideração as identidades sociais, o reconhecimento delas - e a possibilidade de, por meio deste reconhecimento, as identidades serem forjadas por outros -, a presente seção tem como objetivo compilar essas informações, de modo a compreender se há correlação entre o que é dito e o que é reconhecido como a realidade dos refugiados. Para sistematizar a análise, os posicionamentos priorizados são aqueles defendidos por governantes - com foco para os do atual presidente e seus aliados - com tema voltado para a questão de imigrantes e refugiados, amplamente divulgado nos principais meios midiáticos do país.

Nesse sentido, os posicionamentos são analisados de maneira crítica, atentando-se para a representação de "mundos mentais" daqueles que reproduzem conceitos pré-estabelecidos quando tentam descrever o "mundo material", ou a realidade. Ademais, atenta-se, também, para as possíveis forjações de identidades dos refugiados e migrantes que partem de reconhecimentos pautados, em sua maioria, em conotações negativas. Essas informações são, então, cruzadas com dados retirados da pesquisa feita pelo ACNUR, aqui trazida como forma de sistematizar a realidade por eles vivenciada e relatada.

É possível verificar que o discurso acerca da manutenção e recepção de imigrantes e refugiados no Brasil, por parte do atual governo, já se mostrava presente antes mesmo de sua candidatura. Em 2015, o ainda deputado federal Jair Messias Bolsonaro, em entrevista ao Jornal Opção - publicada no dia 18 de setembro no website do periódico -, se referiu a imigrantes haitianos, senegaleses, bolivianos e sírios como sendo a "escória do mundo" (VITOR, 2015). Quatro dias após a entrevista e publicação da matéria pelo Jornal Opção, por meio de um vídeo publicado na plataforma de Youtube no canal de seu filho, o vereador do Rio de Janeiro Carlos Bolsonaro, Jair Bolsonaro se propõe a esclarecer o que quis dizer com o termo "escória do mundo".

No vídeo, intitulado "Refugiados e Bolsonaro: A Verdade", o então deputado explica que "o Norte da África vive atualmente uma situação político-terrorista (...) onde gente de tudo quanto (sic) é origem e credo está saindo daquela região que transformou-se (sic) na antessala do inferno”. Bolsonaro ainda afirma que muitas das pessoas que vem são pessoas “de bem”, mas o problema está 
presente naquelas "de péssima índole” que aproveitam a movimentação para se inserir no cenário brasileiro (BOLSONARO, C., 2015).

Ainda, em resposta a publicação de artigo intitulado "Os refugiados e a esperança" da então Presidente Dilma Rousseff, publicado no Jornal Folha de S. Paulo, em 2015, onde afirma que "neste momento de superação de dificuldades, o Brasil tem os braços abertos para acolher refugiados que queiram viver e trabalhar aqui" (ROUSSEFF, 2015), Jair Bolsonaro afirma que "logicamente, não podemos admitir isso". Para ele faz-se necessário controlar, de forma rígida, a vida pregressa desses indivíduos, incluindo sua cultura, sua educação e seus costumes. "Porque não podemos colocar a nossa sociedade à mercê dessa minoria, escória, que vai se juntar a outra escória que está no Brasil (...) pra impor o terror aqui em nosso país” (BOLSONARO, C. 2015).

Discursos de governantes que escolhem perceber o refúgio por um viés negativo são, gradualmente, normalizados dentro das sociedades, e passam a ser entendidos como aceitáveis. Os dados apresentados no relatório de pesquisa promovido pelo ACNUR mostram que 200 refugiados já sofreram algum tipo de discriminação, e, destes, 147 (representando 73,5\%) foram discriminados pelo fato de serem estrangeiros. A discriminação por meio da xenofobia vem acompanhada pela discriminação racial, com 104 relatos (52\%) e pela discriminação de orientação sexual, com 12,5\% de relatos (ACNUR, 2019, p. 52-53).

Os posicionamentos que evidenciam um reconhecimento negativo em relação aos refugiados e imigrantes também são verificados durante o mandato do presidente Jair Bolsonaro. Após ser eleito no final de 2018, Jair Bolsonaro declarou que adotaria a partir do início do seu mandato um "critério bastante rigoroso" para a entrada de migrantes no Brasil (GONÇALVES, 2019), confirmando, em sua conta do Twitter, que retiraria o Brasil do Pacto Global pela Migração8 da Organização das Nações Unidas (ONU), uma vez que "o Brasil é soberano para decidir se aceita ou não migrantes" (BOLSONARO, J. 2019).

As colocações mais rigorosas frente à entrada de migrantes no país foram também confirmadas pelo ex-chanceler, Ernesto Araújo, em sua conta do Twitter, quando afirmou, na data que foi aprovado o Pacto Global para Migração, que “a imigração é bem-vinda (sic), mas não deve ser indiscriminada. Tem de haver critérios para garantir a segurança tanto dos migrantes quanto dos cidadãos no país de destino. A imigração deve estar a serviço dos interesses nacionais e da coesão de cada sociedade" (ARAÚJO, 2018).

\footnotetext{
${ }^{8} \mathrm{O}$ Pacto Global para Migração é o primeiro acordo global da ONU que propõe uma abordagem comum à migração internacional em todas as suas dimensões. Baseando-se em valores de soberania, o pacote estabelece que cada país tem liberdade de determinar suas políticas de migração, em conformidade com o direito internacional. Ademais, o pacto preza pelo compartilhamento de responsabilidades, pela não discriminação e pelos direitos humanos, além de reconhecer que é necessária uma abordagem cooperativa para otimizar os benefícios gerais da migração, ao mesmo tempo em que aborda os desafios para indivíduos e comunidades nos países da origem, trânsito e destino. O Brasil adotou o Pacto no dia de sua assinatura, em 10 de dezembro de 2018, porém, com a mudança oficial da presidência, dia $1^{\circ}$ de janeiro de 2019, emite telegrama informando sua retirada do pacto (UN, s/d; SPUTNIK, 2019)
} 
É evidente que o tema de migração e refúgio dentro de uma sociedade é um tema complexo. Uma sociedade diversa, de fato, trará opiniões distintas. Um dos resultados dessas percepções pode ser o de entender o refúgio como negativo à sociedade que o acolhe. É necessário, entretanto, que essas opiniões estejam fundamentadas em fatos verídicos e fiéis. A retórica negativa, acompanhada de um reconhecimento baseado puramente em construções que partem do mundo mental e não observam o mundo real daquelas pessoas que solicitam refúgio - forjando negativamente a identidade não somente das pessoas, mas de toda uma nacionalidade, raça ou etnia específica - é problemática, principalmente, quando parte do Presidente da República. Isso porque, como representante do país, ele pode movimentar e normalizar um discurso que reconhece como negativa uma determinada população, simplesmente, por conta de sua origem.

Com efeito, as entrevistas coletadas pelo ACNUR no Brasil, apesar de não investigarem a complacência dos refugiados em abandonarem suas culturas para se adaptarem à brasileira - como parece esperar o Presidente -, mostra que eles têm um grande conhecimento da cultura do país de destino e se interessam por este país e pela vida que podem construir nele. Para 87,2\% dos entrevistados, inclusive, não houve solicitação de refúgio para nenhum outro país além do Brasil (ACNUR, 2019, p. 51).

Ademais, "todos os 487 refugiados entrevistados manifestaram bastante conhecimento da cultura brasileira” (ACNUR, 2019, p. 51). Dentre as manifestações culturais conhecidas destacam-se música, teatro, filmes e livros. Ao observarmos de forma mais profunda, é possível perceber que a música, as telenovelas ou os filmes, por exemplo, são de fácil acesso, por meio da televisão aberta ou das rádios. Já o acesso à literatura e ao teatro brasileiro são mais dificultados, por conta dos altos preços; mesmo assim, um alto número de indivíduos conhece livros e/ou peças de teatro brasileiras - 34,7\% e 27,5\%, respectivamente (ACNUR, 2019, p. 52).

Cabe ainda ressaltar que o acesso a essas manifestações culturais é também modesto pelos próprios brasileiros. Uma pesquisa elaborada pelo Instituto Pró-Livro, em 2016, mostrou que no ano de 2015 os brasileiros leram, em média, 2,43 livros inteiros (Instituto Pró-livro, 2016, p. 68). Já em relação ao teatro, uma pesquisa de 2010, realizada pelo Sistema de Indicadores de Percepção Social (SIPS) do Instituto de Pesquisa Econômica Aplicada (IPEA) indicou que a porcentagem de pessoas que raramente ou nunca vão ao teatro se mantém maior do que 70\% (IPEA, 2010, p. 12).

Outro aspecto cultural a ser analisado diz respeito ao conhecimento da língua portuguesa. Em 2018, o país mantinha um total de 6.5549 refugiados em números acumulados desde 2011. Desses, pelo menos 72\% eram originários de países onde a língua oficial não é o português. Nesse sentido, faz-se importante a análise acerca do conhecimento da língua portuguesa. Os dados obtidos com a pesquisa do ACNUR mostram que 92\% dos refugiados declararam conseguir se comunicar em

\footnotetext{
9 Os dados do texto se referem ao relatório da ACNUR (2019), porém é válido considerar as alterações destes números nos anos seguintes. Até o final de 2020, o número de pessoas refugiadas reconhecidas no país passou para 57.099. Apenas no ano de 2020, o CONARE fez o reconhecimento de 26.577 novas pessoas como refugiados (SILVA et al., 2021).
} 
português. Destes, 53\% afirmam ter frequentado algum curso de português no Brasil (ACNUR, 2019, p. 15). Com base nesses dados, pode-se inferir o interesse que esses indivíduos têm em se integrarem socioculturalmente.

Em março de 2019, Bolsonaro mostrou-se aliado aos preceitos de Donald Trump, então presidente dos Estados Unidos, e a favor da criação do muro que divide o México e os Estados Unidos. Na ocasião, afirmou que "a maioria dos imigrantes não têm boas intenções" (ÁLVARES, 2019), sugerindo que imigrantes não prezam o bem-estar da sociedade em que se inserem. Esse discurso, além de adotar uma visão generalista, carece de argumentos factíveis para se sustentar. Em novo discurso, logo após deixar a Casa Branca, o presidente reconhece algumas falhas na comunicação anterior (SOARES, 2019).

A construção acerca da definição de "boas intenções" é relativa e, portanto, socialmente construída. Nesse caso, a falta de boas intenções percebida pelo presidente faz parte do reconhecimento negativo mencionado anteriormente e da criação de uma identidade a qual, em grande parte, não condiz com a forma como esse grupo se reconhece em termos identitários. Por esse motivo, como forma de identificar as "boas intenções" dos refugiados, utilizam-se como variáveis questões relacionadas à educação, à empregabilidade e as suas expectativas com a nova vida que terão no Brasil.

Ao investigar o desejo de votar nas eleições brasileiras, ou seja, o desejo de se integrar à comunidade política nacional, observa-se uma vontade de conquistar mais do que apenas a condição de observador neutro. Os entrevistados mostram um interesse de superarem a circunstância de apenas serem considerados objeto das políticas públicas e das decisões nacionais, e querem participar ativamente desses processos. Dos $474^{10}$ entrevistados questionados acerca da possibilidade de voto nas eleições brasileiras, 80,6\% mostraram possuir interesse em participar dos pleitos políticos brasileiros. Dessa maneira, percebe-se que os refugiados, em sua maioria, desejam tornar-se atores relevantes "com direito a voz e a voto, ultrapassando assim a condição clássica de estrangeiro" (ACNUR, 2019, p. 49-50).

Já em relação ao interesse em obter nacionalidade brasileira, percebe-se que a maioria 96,3\% do total - manifestou-se favorável e interessada em obter o status de cidadão brasileiro (ACNUR, 2019, p. 50). A manifestação do desejo de se tornarem também cidadãos brasileiros pode ser contraposta com o ideal de Estado-nação, mencionado anteriormente, em que se entende a cidadania como sendo o modo correto de pertencer a um Estado. Diante disso, verifica-se um grande potencial integrativo, uma vez que, ao serem cidadãos brasileiros, deixariam de ser entendidos como "o outro", facilitando assim o processo de integração socioeconômica.

\footnotetext{
${ }^{10} \mathrm{O}$ número de 474 respostas para esta pergunta específica, diferente do total de 487 entrevistados, dá-se, muitas vezes, por conta da recusa do entrevistado em responder à questão, que pode partir da não compreensão da pergunta ou do receio que o indivíduo pode sentir ao se comprometer em respondê-la. Será possível identificar ao longo deste artigo algumas perguntas onde o total de respondentes é diferente do total de entrevistados no relatório.
} 
Outro dado que oferece uma visão sobre as "boas intenções" dos refugiados é quando estes são questionados sobre as escolhas que os trouxeram ao Brasil. Ao serem questionados se fariam uma nova solicitação de refúgio no Brasil e se teriam, ainda, desejo de vir ao país depois de conhecer a realidade brasileira, 77,8\% responderam que "sim". Quando questionados sobre o desejo de permanecer definitivamente no país, 444 respondentes confirmaram esse desejo. As respostas a essas perguntas indicam uma forte crença no futuro que podem ter no país, com maior integração à sociedade.

\begin{abstract}
Todos esses indicadores (...) demonstram que, apesar das dificuldades com emprego e com revalidação de diplomas, altas jornadas de trabalho e salários considerados insuficientes, os refugiados acreditam em sua capacidade de adaptação e ascensão social no país. São projetos de vida que, em princípio, desejam construir com seus familiares. Em resumo, o Brasil, nesse momento, apresenta-se como uma opção (...) definitiva para a população refugiada analisada (ACNUR, 2019, p. 54).
\end{abstract}

O que pode ser notado, nas entrelinhas do que a pesquisa traz, é que os refugiados carregam grandes expectativas em relação ao estabelecimento de uma nova vida no Brasil. Apesar de certas expectativas serem fundadas em interesses próprios - como a inserção no mercado de trabalho para garantir um salário que lhes ofereça a possibilidade de sustento próprio -, é possível identificar vontades reais de integração à sociedade brasileira, além da identificação de que esses interesses contribuem para o desenvolvimento da economia local - beneficiando, por consequência, o Brasil. Essas vontades permanecem mesmo com todas as dificuldades que esses indivíduos enfrentam.

Assim, talvez suas próprias culturas, religiões, ou o que faz parte de sua essência como indivíduos, nascidos nos mais variados países, não sejam abandonadas - e, em realidade, não deveriam ser, uma vez que isso faz parte de suas identidades e de como se reconhecem. Isso não indica, porém, que estes não possuam "boas intenções", uma vez que estas podem ser integradas às expectativas que esses indivíduos carregam em relação à sua integração na sociedade brasileira.

Pode-se, também, expandir a avaliação das "boas intenções" dos refugiados não somente para a análise de suas expectativas, mas também para o que podem oferecer à sociedade brasileirao que diz respeito às suas vidas pregressas. Nesse sentido, quando analisada a escolaridade dos refugiados entrevistados, é possível identificar que dentre os 487 refugiados entrevistados, 242 (49,7\%) possuem no mínimo Ensino Médio completo, e 151 (31\%) possuem nível superior completo (ACNUR, 2019, p. 59), mostrando um desenvolvimento pessoal impressionante e uma possibilidade de adição importante à sociedade brasileira. Ainda, 290 (59,5\%) refugiados entrevistados apresentaram interesse em dar seguimento aos seus estudos no Brasil (ACNUR, 2019, p. 17).

Posto que um bom nível educacional é visto como positivo pela sociedade brasileira, entendese que essa variável pode auxiliar a sustentar o fato de que os refugiados apresentam "boas intenções”. No entanto, uma das grandes dificuldades encontradas pelos refugiados, que possuem no mínimo ensino superior completo, diz respeito à revalidação de seus diplomas. Cerca de 90\% dos entrevistados não obtiveram sucesso na revalidação de seus diplomas, por conta de falta de 
informação, burocracia do processo ou dificuldade na tradução de documentos (ACNUR, 2019, p. 14).

A relação do atual governo com a questão dos refugiados se apresenta de forma ambígua: por um lado adotam-se algumas medidas que estimulam o sentimento de não-pertencimento e a busca pelo controle excessivo de entrada das pessoas ao país - além do controle de aspectos identitários desses indivíduos -; por outro, adotam medidas que auxiliam na integração desses indivíduos. Ainda no início de 2019, o recém-eleito presidente da república liberou um montante para o acolhimento dos refugiados venezuelanos. Em abril do mesmo ano, Bolsonaro assinou uma medida provisória (MP 880/19) que liberava 224 milhões de reais para assistência emergencial e acolhimento humanitário dos refugiados da Venezuela (NEVES, 2019).

Em contrapartida, um mês após a implementação dessa medida, o deputado federal Eduardo Bolsonaro, filho do atual presidente, visitou cidades de Roraima e afirmou, em um vídeo divulgado em seu Twitter, que os benefícios assistencialistas aos refugiados geram efeitos negativos para o país. O deputado federal declarou que a vinda de venezuelanos ao Brasil não seria, essencialmente, por conta de necessidades que este grupo estaria enfrentando em seu país de origem, mas sim, por conta do interesse no assistencialismo brasileiro - principalmente pelo programa "Bolsa Família" (BOLSONARO, E. 2019).

Tal afirmação vai de encontro aos dados coletados na amostra, uma vez que $33 \%$ dos entrevistados afirmam desconhecer qualquer direito e dever ligado à sua condição de refugiado outros 33,3\% os conhecem apenas parcialmente (ACNUR, 2019, p. 41). Ainda, quando questionados acerca dos serviços públicos brasileiros por eles acessado, 59\% afirmaram não ter utilizado nenhum serviço público de educação, 80\% não se valeram de assistência social disponível e mais de 85\% não tiveram acesso a previdência social. Além disso, os benefícios sociais - como o Benefício de Prestação Continuada (BPC) e/ou os programas de transferência de renda - estão atingindo apenas 17,8\% dos refugiados (ACNUR, 2019, p. 42-43).

Ainda, acerca das críticas proferidas por Eduardo Bolsonaro, dos 487 refugiados entrevistados, cerca de 60\% informaram estar inseridos no mercado de trabalho, indicando que não possuem interesse exclusivo em assistencialismo, e buscam formas de se estabelecerem no país. Essa integração, por sua vez, beneficia e movimenta a economia brasileira, mesmo que a atuação desses indivíduos não seja nas áreas em que estes têm estudos ou expertise - já que 68\% dos refugiados não aproveitam sua profissão ou ofício prévio na ocupação atual (ACNUR, 2019, p. 31).

Em novembro de 2019, o governo brasileiro, em parceria com o ACNUR, o Banco Central e o Ministério da Justiça e Segurança Pública lançou uma cartilha financeira com o objetivo de informar migrantes e refugiados sobre o processo de abertura de contas, operações de câmbio, envio e recebimento de remessas ao(do) exterior, e solicitação de empréstimos (Ministério da Justiça e Segurança Pública, (s/d)). Trata-se de uma medida de grande importância, uma vez que, de acordo com os dados obtidos na pesquisa acerca do perfil socioeconômico dos refugiados no Brasil, apesar 
de 79,7\% dos refugiados entrevistados possuírem conta bancária, a grande maioria não utiliza os demais serviços financeiros disponíveis como crédito, microcrédito e seguro (ACNUR, 2019, p. 26).

Desde 2018, com o aumento no fluxo de venezuelanos, estabeleceu-se no Brasil a "Operação Acolhida”, "uma grande força-tarefa humanitária executada e coordenada pelo Governo Federal com o apoio de agências da ONU e de mais de 100 entidades da sociedade civil” (Operação Acolhida, s/d). Essa operação tem como objetivo oferecer assistência emergencial aos imigrantes venezuelanos que buscam melhores condições de vida no Brasil. Diante desse cenário de crescente fluxo - estimase que, até outubro de 2020, existam mais de 258 mil venezuelanos migrantes e refugiados no Brasil (R4V, s/d) -, ainda em outubro de 2019 o presidente Jair Bolsonaro assinou um acordo para ampliar o número de municípios que recebem venezuelanos, com o objetivo de interiorizar a acolhida e criar melhores oportunidades de inserção desses refugiados (PIERI, 2019). Essa política, além de oferecer novas perspectivas aos refugiados venezuelanos, acaba também diminuindo a pressão sobre os serviços públicos de um único ente federativo - principalmente, Roraima -, fazendo assim com que os demais estados possam também acolhê-los.

Apesar de a Cartilha e a Operação Acolhida serem propostas relevantes que colaboram para o maior acolhimento dos refugiados no país, não contemplam ou representam a real necessidade dos refugiados em sua totalidade. A Cartilha, por um lado, tem o foco em informações voltadas para questões financeiras. Apesar de informações importantes e pertinentes, essas não contemplam as necessidades mais básicas que precisam ser passadas aos refugiados quando se instalam no país, como informações relevantes sobre acesso aos cursos de português ou aos direitos que possuem quando acolhidos no país. Assim, a população refugiada permanece com pouco conhecimento sobre seus direitos e sua integração à sociedade brasileira permanece rasa.

A Operação Acolhida, por outro lado, auxilia na proposta de que os refugiados sejam recebidos em diversos entes federativos, de modo a aliviar a pressão estabelecida apenas em Roraima que, por ser um estado fronteiriço, evidencia uma porosidade na fronteira e se torna o estado de permanência de muitos refugiados que se percebem seguros, uma vez que conseguem deixar sua condição na Venezuela. Uma possível lacuna na operação é o fato de não contemplar outras nacionalidades que tem número maior de acolhida. O controle de acesso de sírios, por exemplo nacionalidade com maior número de refugiados no Brasil -, é mais simples do que o de venezuelanos. Assim, a operação pode ser percebida como uma forma de controle dos refugiados venezuelanos, ao invés de ser considerado um projeto voltado e pensado na realidade desses indivíduos que se integram ao Estado Brasileiro.

\section{CONSIDERAÇÕES FINAIS}


Os dados levantados no artigo nos mostram que os discursos baseados em identidades forjadas e reconhecimentos negativos dos refugiados acompanham o atual governo brasileiro desde antes da eleição de Bolsonaro à presidência. Já em 2015, o então deputado federal referia-se aos imigrantes como sendo a "escória do mundo". Tal discurso se mantém presente nos dias atuais, e é proferido não apenas pelo presidente, mas também por seus aliados - como seus filhos, o vereador Carlos e o deputado federal Eduardo e, também, seu ex-Ministro das Relações Exterior, Ernesto Araújo. O "mundo mental" das críticas e dos discursos direcionados aos refugiados - normalmente travestidos de conotações negativas - acabam sendo visivelmente desmascarados quando contrapostos com a realidade vivida pelos refugiados.

A ideia que é propagada, de que os migrantes são um problema para os Estados que os recebem - por não abandonarem suas raízes -, ao ser contraposta com a identificação dos refugiados com a cultura brasileira, mostra que não há a necessidade de se abandonar uma cultura em detrimento da outra, mas sim que ambas podem formar um conjunto que integra a identidade desses refugiados no país de destino. A concepção de que refugiados são indivíduos que não possuem "boas intenções" pode ser confrontada com os dados que informam que eles possuem altos graus de escolaridade, têm interesse em continuar seus estudos no Brasil, e estão, em sua maioria, inseridos no mercado de trabalho. Ou seja, os aspectos relacionados a "boa intenção" desses indivíduos estão presentes no cotidiano dos refugiados, que vem ao Brasil em busca de mais segurança e melhores condições de vida.

Ainda, as críticas que acabam sendo amplamente difundidas aos refugiados, como sendo indivíduos que buscam apenas uma fonte de assistencialismo, acabam perdendo força quando se apontam os dados relativos ao acesso de refugiados aos sistemas públicos de educação, saúde, assistência social e previdência social. Esses mostram que é baixa a parcela de refugiados que possui, procura ou, até mesmo, conhece seu acesso a essas políticas, mesmo que seja seu direito.

$\mathrm{O}$ artigo teve como objetivo desmistificar a conotação negativa que o termo refugiado carrega, principalmente, nas práticas discursivas dos governantes, fruto de um reconhecimento pautado na criação de identidades negativas deste grupo. Trata-se de uma necessidade latente em nível social, uma vez que propicia visualizar que são as próprias estruturas - e aqueles que delas fazem parte - que tornam estes grupos invisíveis, impõe a eles a conotação negativa e os excluem da sociedade. Dessa forma, verifica-se que os discursos proferidos pelo presidente Jair Bolsonaro e seus aliados forjam negativamente a identidade dos refugiados, promovendo uma imagem que, na verdade, é estabelecida no plano hipotético - no "mundo mental” - e influenciada pelas suas crenças, e não na interpretação da realidade.

*Artigo recebido em 31 de maio de 2021, aprovado em 28 de outubro de 2021. 


\section{REFERÊNCIAS}

ACNUR (Alto Comissariado das Nações Unidas para os Refugiados). Perfil Socioeconômico dos Refugiados no Brasil: subsídios para elaboração de políticas. Resumo Executivo. 2019. Disponível em: https://www.acnur.org/portugues/wp-content/uploads/2019/o7/Pesquisa-PerfilSocioecon\%C3\%B4mico-Refugiados-ACNUR.pdf; Acesso em: 15/o3/2020.

ACNUR (Alto Comissariado das Nações Unidas para os Refugiados). Declaração de Cartagena. 1984. Disponível em: https://www.acnur.org/fileadmin/Documentos/portugues/BD Legal/Instrumentos Internaciona is/Declaracao de Cartagena.pdf?view=1; Acesso em: 20/06/2019.

ACNUR (Alto Comissariado das Nações Unidas para os Refugiados). Convenção de Genebra. 1984.

Disponível

em:

https://www.acnur.org/fileadmin/Documentos/portugues/BDL/Convencao_relativa_ao_Estatuto _dos_Refugiados.pdf; Acesso em: 20/06/2019.

ADLER, Emanuel. Seizing the Middle Ground: constructivism in world politics. European Journal of International Relations, v. $3, \quad$ n. $\quad 3, \quad$ set. 1997. https://doi.org/10.1177/1354066197003003003.

ÁLVARES, Débora. “Maioria dos imigrantes não tem boas intenções”, diz Bolsonaro a TV dos Estados Unidos. Congresso em Foco, 19 Mar. 2019. Disponível em: https://congressoemfoco.uol.com.br/governo/a-emissora-norte-americana-bolsonaro-diz-quemaioria-dos-imigrantes-nao-tem-boas-intencoes/; Acesso em: 12/04/2020.

ARAÚJO, Ernesto. 1/A imigração é bem vinda, mas não deve ser indiscriminada. Tem de haver critérios para garantir a segurança tanto dos migrantes quanto dos cidadãos no país de destino. A imigração deve estar a serviço dos interesses nacionais e da coesão de cada sociedade. Brasil, 10 de dezembro de 2018. Twitter: @ernestofaraujo. Disponível em: https://twitter.com/ernestofaraujo/status/1072252891887472645? ref src=twsrc\%5Etfw\%7Ctwca mp\%5Etweetembed\%7Ctwterm\%5E1072252891887472645\&ref url=https\%3A\%2F\%2Fwww.pode r360.com.br\%2Fgoverno\%2Fbolsonaro-diz-que-adotara-1-criterio-rigoroso-para-entrada-deimigrantes\%2F; Acesso em: 08/03/2020.

BATISTA JR., Paulo Nogueira. O Brasil Não Cabe no Quintal de Ninguém. São Paulo: LeYa, 2019.

BETTS, A.; BLOOM, L.; KAPLAN, J.; OMATA, N. Refugee Economies: forced displacement and development. United Kingdom: Oxford University Press, 2017.

BOLSONARO, Carlos. Refugiados e Bolsonaro: a verdade. Youtube. 2015. (3m12s). Disponível em: https://www.youtube.com/watch?v=t9AIyunctsU\&t=3s; Acesso em: 08/03/2020.

BOLSONARO, Eduardo. COLAPSO EM RORAIMA: SOFREM VENEZUELANOS E TAMBÉM BRASILEIROS. Venezuelanos fugindo da narcoditadura são bem vindos, mas não pode haver atrativo assistencialista para que nós sejamos provedores do mundo inteiro. Brasil, 2 de Maio de 2019. Twitter: @BolsonaroSP. Disponível em: https://twitter.com/BolsonaroSP/status/1124025838721273856; Acesso em: 11/05/2020.

BOLSONARO, Jair Messias. Pacto Migratório. Brasil, o9 de janeiro de 2019. Twitter: @jairbolsonaro. Disponível em: https://twitter.com/jairbolsonaro/status/1082924268361519104.; Acesso em: 08/03/2020. 
BRASIL. Lei 9.474/1997: Define mecanismos para a implementação do Estatuto dos Refugiados de 1951, e determina outras providências. 1997. Disponível em < http://www.planalto.gov.br/ccivil 03/leis/l9474.htm>; Acesso em: 13/05/2019.

CASTLES, Stephen. The International Politics of Forced Migration. Development, v. 46, n. 3, p. 11-20, 1 set. 2003. Springer Science and Business Media LLC. http://dx.doi.org/10.1177/10116370030463003.

FAIRCLOUGH, Norman. Analysing Discourse: textual analysis for social research. London: Routledge, 2003.

GONÇALVES, Carolina. Bolsonaro confirma revogação da adesão ao Pacto Global para Migração. Agência Brasil, o9 jan. 2019. Disponível em: https://agenciabrasil.ebc.com.br/politica/noticia/2019-01/bolsonaro-confirma-revogacao-daadesao-ao-pacto-global-para-migracao; Acesso em: 23/04/2020.

HADDAD, Emma. The Refugee in International Society: between sovereigns. New York: Cambridge University Press, 2008.

Instituto Pró Livro. Retratos da Leitura no Brasil. $4^{\text {a }}$ Edição. Março, 2016. Disponível em: http://prolivro.org.br/home/images/2016/Pesquisa_Retratos_da_Leitura_no_Brasil__2015.pdf; Acesso em: 15/04/2020.

Instituto de Pesquisa Econômica Aplicada (IPEA). Sistema de Indicadores de Percepção Social (SIPS): $\quad$ Cultura. 2010. https://www.ipea.gov.br/portal/images/stories/PDFs/SIPS/101117_sips_cultura.pdf; Acesso em: 15/04/2020.

JACOBSEN, Karen. Can refugees benefit the state? Refugee resources and African statebuilding. The Journal Of Modern African Studies, v. 40, n. 4, p. 577-596, 28 nov. 2002. Cambridge University Press (CUP). http://dx.doi.org/10.1017/s0022278x02004081.

KOWERT, Paul; LEGRO, Jeffrey. Norms, Identity and Their Limits: a theoretical reprise: A Theoretical Reprise. In: KATZENSTEIN, P.J. The Culture of National Security: norms and identity in world politics. Norms and Identity in World Politics. New York: Columbia University Press, 1996. pp. 358-395.

LAURETTI, Patrícia. Estudo revela superexploração de mão de obra de haitianos em Santa Catarina. Jornal da Unicamp, 16 Mai. 2017. Disponível em: https://www.brasildefato.com.br/2017/05/16/estudo-revela-superexploracao-de-mao-de-obra-dehaitianos-em-santa-catarina; Acesso em: 05/05/2020.

\section{MINISTÉRIO DA JUSTIÇA E SEGURANÇA PÚBLICA. Cartilha de informações financeiras} para migrantes e refugiados. Brasília, (s/d). Disponível em: https://www.novo.justica.gov.br/news/cartilha-de-informacoes-financeiras-para-migrantes-erefugiados; Acesso em: 0705/2020.

MOREIRA, Julia Bertino. Refugiados no Brasil: Reflexões acerca do processo de integração local. Rev. Interdiscip. Mobil. Hum., Brasília, Ano XXII, n. 43, p. 85-98, jul./dez. 2014.

NEVES, Rafael. Bolsonaro libera $\mathbf{R} \$ 224$ milhões para acolhimento a refugiados venezuelanos. Congresso em foco, Brasília, 30 de abril de 2019. Disponível em: https://congressoemfoco.uol.com.br/especial/noticias/bolsonaro-libera-r-224-milhoes-paraacolhimento-a-refugiados-venezuelanos/; Acesso em: 09/04/2020. 
Operação Acolhida. A Operação Acolhida. s/d. Disponível em: https://www.gov.br/acolhida/historico/; Acesso em: 15/10/2019.

PIERI, Bruna de. Bolsonaro assina acordo para ampliar número de municípios que recebem venezuelanos. Terça Livre, 03 out. 2019. Disponível em: https://www.tercalivre.com.br/bolsonaro-assina-acordo-para-ampliar-numero-de-municipiosque-recebem-venezuelanos/; Acesso em: 24/03/2020.

R4V. R4V info: Brazil Data. s/d. Disponível em: <https://www.r4v.info/pt/brazil >. Acesso em: 19 Oct. 2021.

ROUSSEFF, Dilma. Os refugiados e a esperança. Folha de S. Paulo, São Paulo, 10 set. 2015. Opinião. Disponível em: https://m.folha.uol.com.br/opiniao/2015/o9/1679691-os-refugiados-e-aesperanca.shtml; Acesso em: 23/o3/2020.

SILVA, G. J; CAVALCANTI, L; OLIVEIRA, T; COSTA, L. F. L; MACEDO, M. Refúgio em Números, $6^{a}$ Edição. Observatório das Migrações Internacionais; Ministério da Justiça e Segurança Pública/ Comitê Nacional para os Refugiados. Brasília, DF: OBMigra, 2021.

SOARES, Jussara. Bolsonaro volta atrás: 'Maioria dos imigrantes tem boas intenções'. O Globo, Washington, 20 Mar. 2019. Disponível em: https://oglobo.globo.com/mundo/bolsonaro-voltaatras-maioria-dos-imigrantes-tem-boas-intencoes-23534610; Acesso em: 17/03/2020.

SPUTNIK. Brazil Confirms Exit From UN Global Migration Compact - Reports. Sputnik news. 09 Jan. 2019, Latin America. Disponível em: https://sputniknews.com/latam/201901091071315759-exit-brazil-un-migration-compact/; Acesso em: 26/04/2020.

United Nations (UN). Global compact for migration. s/d. Disponível em: https://refugeesmigrants.un.org/migration-compact; Acesso em: 25/04/2020.

VITOR, Frederico. Bolsonaro vê imigrantes como "ameaça" e chama refugiados de "a escória do mundo". Jornal opção, n. 2097, 18 set. 2015. Entrevista. Disponível em: https://www.jornalopcao.com.br/ultimas-noticias/bolsonaro-ve-imigrantes-como-ameaca-echama-refugiados-de-a-escoria-do-mundo-46043/; Acesso em: 23/03/2020. 